\title{
A SZÁNTÓFÖLDI NÖVÉNYTERMELÉS TELJES TÉNYEZŐS TERMELÉKENYSÉGÉNEK VÁLTOZÁSA MAGYARORSZÁGON 2004 ÉS 2015 KÖZÖTT
}

\author{
Lászlók Anett
}

\section{Összefoglalás}

A tanulmány Malmquist index segitségével vizsgálja a magyarországi szántóföldi növénytermelés teljes tényezös termelékenységének változását üzemméret szerinti bontásban 2004 és 2015 között. A Malmquist index a hatékonyságot a burkolófelület elemzés (Data Envelopment Analysis - DEA) módszerével elóállitott határfüggvénytöl való távolsággal méri. Az index a termelékenységváltozás okainak feltárásához további információkat is szolgáltat azzal, hogy annak értékét összetevökre bontja fel. Az eredmények szerint a szántóföldi növénytermelés termelékenysége a vizsgált idöszakban kismértékben növekedett, ami a technikai hatékonyság növekedésének volt köszönhetö. Méretkategóriánként vizsgálva a közepes méretü üzemek érték el a legnagyobb termelékenység növekedést, míg a kisméretü élvonalbeli üzemek termelési szintje került közelebb az adott technológia által maximálisan elérhetö termelési lehetöségek határához.

Kulcsszavak: teljes tényezös termelékenység, Malmquist index, hatékonyság, szántóföldi növénytermelés

JEL: D24

DOI: 10.33032/acr.2019.9.1.133 


\title{
CHANGES IN THE TOTAL FACTOR PRODUCTIVITY OF ARABLE CROP PRODUCTION IN HUNGARY BETWEEN 2004 AND 2015
}

\begin{abstract}
The study uses a Malmquist index to investigate changes in the total factor productivity of arable crop production in Hungary, broken down by farm size between 2004 and 2015. The Malmquist index measures efficiency by the distance from the boundary function generated by the Data Envelopment Analysis (DEA) method. The index also provides additional information to explore the causes of productivity change by breaking down its value into components. According to the results, the productivity of arable crop production increased slightly during the period under review, due to the increase in technical efficiency. Looking at the size category, medium-sized plants have achieved the highest productivity growth, while the production level of small-scale leading plants has come closer to the limit of the maximum production potential of the technology.
\end{abstract}

Keywords: Total Factor Productivity, Malmquist index, efficiency, arable crop production

JEL: D24 


\section{Bevezetés}

Magyarország természetföldrajzi adottságai szántóföldi növénytermelésre igen kedvezőek. Az éghajlati tényezők (csapadék, hőmérséklet, napfény) és a domborzati viszonyok kedvező feltételeket teremtenek a mezőgazdálkodás, ezen belül a szántóföldi növénytermelés számára. Az ipari és a szolgáltató ágazatok dinamikus fejlődése miatt a mezőgazdaság bruttó hazai terméken (GDP) belüli részaránya az elmúlt 20 évben csaknem a felére csökkent, az abszolút termelési érték viszont nőtt. 2016-ban a GDP termeléséhez a mezőgazdaság 3,7\%-kal járult hozzá, szemben az 1995. évi 7,1\%-kal.

Az uniós csatlakozást követően, köszönhetően a bővülő támogatási rendszernek, lassan javulni kezdett az agrárvállalkozások jövedelmezősége, viszont meg kell jegyezni, hogy a jövedelmezőség erősen támogatásfüggő is. (BARANYI et al., 2012) Magyarországon az egy lakosra jutó mezőgazdasági terület másfélszerese az Európai Unió átlagának. Az ország saját népessége ellátásán túl jelentős mezőgazdasági exportárualap előállítására is képes lenne. Ez azonban az utóbbi 20-25 évben kihasználatlan maradt, elsősorban az ágazat alacsony jövedelmezősége miatt. 1970 és 1980 között Magyarország több mezőgazdasági terméke is (pl. búza, kukorica, napraforgó) az egy főre jutó termelés esetében a világ első három helyezettje közé került, majd az exportpiacok beszűkültek és a belső piaci kereslet tartósan visszaesett (SOMAI, 2004).

A prognózisok szerint Magyarország lakossága folyamatosan csökkenni fog. A népesség várhatóan 2030-ban 9 milliárd fő körül fog alakulni, ezért a mezőgazdasági termelés növelése csak akkor indokolt, ha a keletkezett terméktöbblet gazdaságosan exportálható, vagy valamilyen más erőforrás (pl. üzemanyag) pótolható vele.

\section{Anyag és módszer}

\section{Anyag}

Az elemzés az Agrárgazdasági Kutató Intézet (AKI) költség és jövedelem adataiból készült 2004 és 2015 közötti évekre vonatkozóan. Az adatbázisból a Malmquist index számításához két output és hét input adatot használtam fel, melyek a következők:

Output 1: Főtermék mennyisége kilogrammban,

Output 2: Az ágazat összes árbevétele forintban,

Input 1: Vetésterület hektárban,

Input 2: Átlagos aranykorona érték Ark/ha-ban,

Input 3: Vetőmag-, szaporítóanyag költség forintban,

Input 4: Műtrágyaköltség forintban, 
Input 5: Növényvédő szer költsége forintban,

Input 6: Gépköltségek forintban,

Input 7: Ledolgozott munkaórák száma órában.

Az üzemek méretkategóriák szerinti csoportosítása a Standard Termelési Érték (STÉ) alapján történt. Az STÉ az ágazatok kibocsátását számszerűsíti, ami a termelési érték és a közvetlen támogatások különbségeként számítható ki. Az elemzés megkönnyítése érdekében az AKI által gyűjtött 12 méretkategóriából három csoportot képeztem (3-5 STÉ, 6-9 STÉ és 10-14 STÉ).

A Malmquist index számításához azoknak az üzemeknek az adatait használtam fel az AKI adatbázisából, amelyek a vizsgált időszak minden évében gazdasági tevékenységet folytattak 2004 és 2015 év között. A vizsgált időszakban 398 olyan üzem volt a mintában, amelyik folyamatosan végzett termelő tevékenységet. Mivel a termelékenység számításához felhasznált DEAP Version 2.1 program érzékeny a nulla értékre, ezért az adatbázist meg kellett tisztítani a kiugró értékektől. Így a mintából kiestek azok az üzemek, amelyek nem számoltak el gépköltséget, mert idegen gépi szolgáltatásokat vettek igénybe, vagy nem használtak fel műtrágyát és növényvédő szereket, illetve saját felhasználásra termelték meg a gabonát, nem pedig érékesítésre. A kiugró értékek törlése után 304 üzem maradt a mintában, amelyekre a számításokat elvégeztem, így egy év adatát a 304 üzem hatékonyságának mértani átlaga adja. A DEA módszeren alapuló Malmquist index nem igényli a hasonló mértékegységek alkalmazását, így nem szükséges az adatokat számítás előtt standardizálni. Az árváltozás kiszűrése érdekében a mezőgazdasági termelői árak indexével defláltam az input és output adatokat, 2004. évet bázisul véve.

\section{Módszer}

A Malmquist index a hatékonyságot a burkolófelület elemzés módszerével (Data Envelopment Analysis - DEA) előállított határfüggvénytől való távolsággal méri. A Malmquist index alkalmas országok, régiók, vállalatok és más döntési egységek hatékonyságának összehasonlítására egy adott output/input vektor és a vizsgált mintában leghatékonyabbnak ítélt egység output/input aránya közötti távolság mérése alapján. A termelési függvény értékeit minden inputszinthez a mintában szereplő egységek közül a legjobb teljesítményüek kibocsátási adatai adják. Az index a vizsgált egység hatékonyságát relatív módon méri a legjobb teljesítményt elérő referencia csoporthoz képest (FARKASNÉ FEKETE et al., 2008). Az index lehet output, vagy input-orientált. A DEA módszer értelmezését és az input/outputorientáció különbségét mutatja az 1 . ábra. 


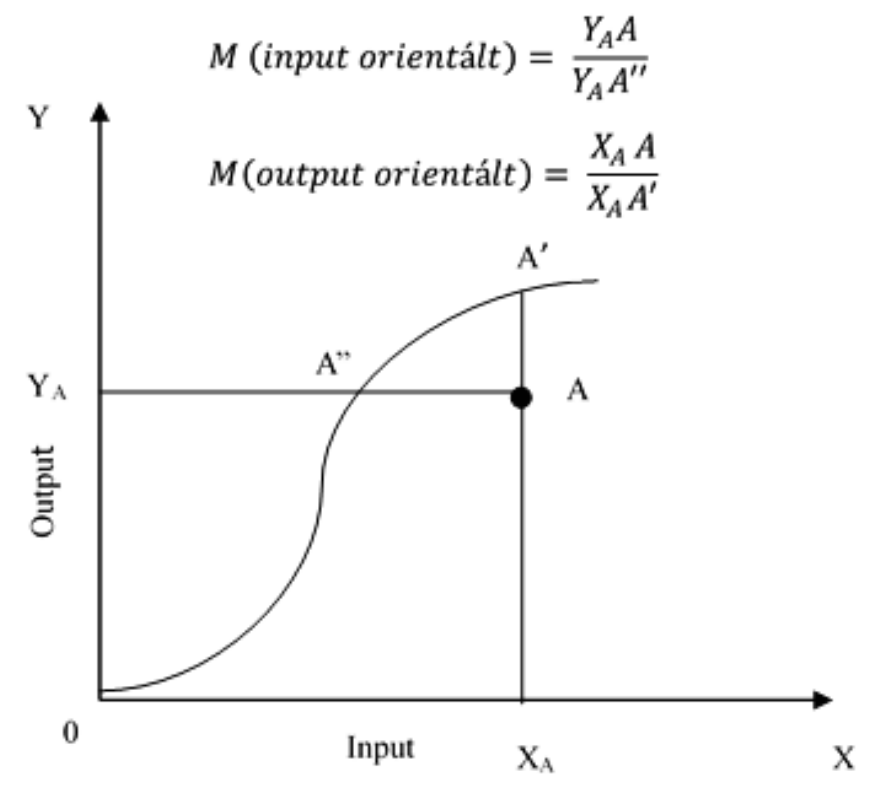

1. ábra: Az input és output orientált Malmquist index értelmezése

Forrás: FARKASNÉ FEKETE et al., 2009. 104 p. alapján saját szerkesztés

$\mathrm{Az}$ input orientált politika az output változatlan tartása mellett az input megváltoztatásával kívánja növelni a hatékonyságot. Az output orientált politika pedig az input változatlan tartása mellett próbálja növelni az outputot. A két szemlélet nem befolyásolja a határfüggvényt, mert adott technikai szinten a legjobb teljesítményt nyújtók ugyanazok a döntési egységek (üzemek) maradnak.

Számításaim során Malmquist index segítségével az output-orientált teljes tényezős termelékenység (Total Factor Productivity - TFP) számítását végeztem el. A Malmquist index a következőképpen számítható ki (COELLI et al., 2005):

$$
m_{o}^{t+1}=\left[\frac{d_{o}^{t}\left(x_{t+1}, y_{t+1}\right)}{d_{o}^{t}\left(x_{t}, y_{t}\right)} \times \frac{d_{o}^{t+1}\left(x_{t+1}, y_{t+1}\right)}{d_{o}^{t+1}\left(x_{t}, y_{t}\right)}\right]^{1 / 2}
$$

Az index az adatokat két különböző időpontban ( $t$ és $t+1)$ hasonlítja össze, a $\mathrm{t}$ időszakhoz tartozó technológiai szinten (FÄRE - GROSSKOPF, 1998). $\mathrm{Az}$ index felbontható a technológiai hatékonyságváltozás (TC) és a technikai hatékonyságváltozás (TEC) mutatókra. A technikai hatékonyságváltozás tovább bontható a skálahatékonyság-változás (SC) és a tiszta technikai hatékonyságváltozás (PU) mutatókra. 


$$
m_{o}^{t+1}=\frac{d_{o}^{t+1}\left(x_{t+1}, y_{t+1}\right)}{d_{o}^{t}\left(x_{t}, y_{t}\right)} \times\left[\frac{d_{o}^{t}\left(x_{t+1}, y_{t+1}\right)}{d_{o}^{t+1}\left(x_{t+1}, y_{t+1}\right)} \times \frac{d_{o}^{t}\left(x_{t}, y_{t}\right)}{d_{o}^{t+1}\left(x_{t}, y_{t}\right)}\right]^{1 / 2}
$$

$$
T F P=T C \times(S C \times P U)
$$

A technológiai hatékonyság a termelési függvény eltolódását, vagy is az élvonalbeli döntési egységek teljesítményének változását méri, míg a technikai hatékonyság a legjobb teljesítménytől való lemaradást mutatja. A technikai hatékonyság felbontható skálahatékonyságra és tiszta technikai hatékonyságra. A skálahatékonyság a termelés méretének változásából adódó hatékonyságváltozást jelenti. A tiszta technikai hatékonyság mutató mutatja az eddig nem számszerűsített, egyéb okokból bekövetkezett hatékonyságváltozást, mint például a menedzsment felkészületlenségéből adódó lemaradást, vagy a termelési tényezők optimálistól eltérő felhasználását. Ha az index értéke nagyobb, mint egy, akkor a hatékonyság javult a két időszak között, ha kisebb, mint egy, akkor romlott.

\section{Eredmények}

A kapott eredmények szerint a teljes tényezős termelékenység évenként jelentős ingadozásokat mutat, ami alapvetően az időjárás változásának tulajdonítható. Ezt a hatást már BARÁTH et al. (2009) is azonosították tanulmányukban. Az üzemek teljesítménye az időjárástól függően nagymértékű szóródást mutathat, ami kedvező időjárási viszonyok esetén könnyen egyes termékek túltermeléséhez vezet.

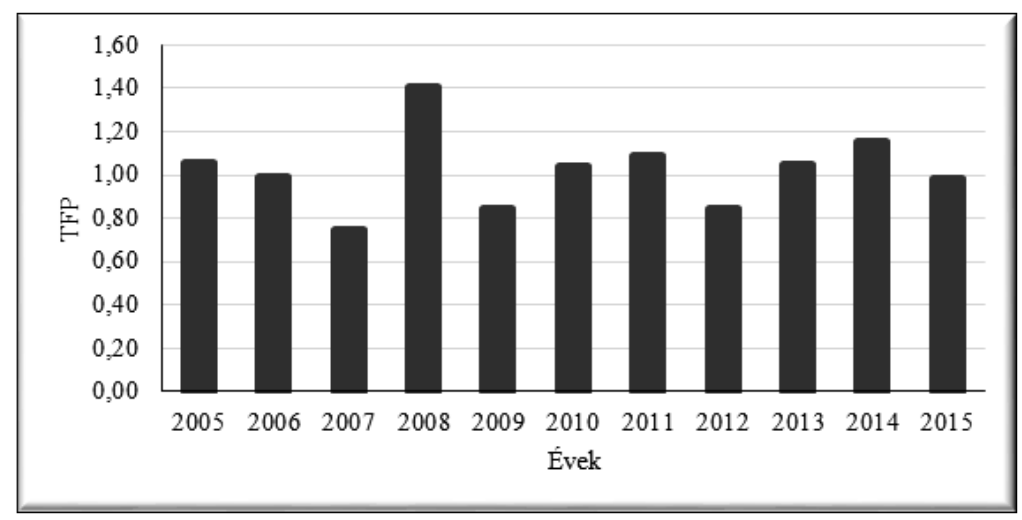

2. ábra: A teljes tényezős termelékenyég alakulása

Forrás: AKI adatok alapján saját számitás, DEAP 
A növények többségénél 2008. és 2014. évben a kedvező időjárási feltételeknek köszönhetően a magasabb hozamok miatt magasabb volt a TFP értéke, míg 2007. és 2012. évben a kedvezőtlen időjárás miatti alacsony hozamok okozták a TFP értékének csökkenését (2. ábra). Kedvezőbb időjárási feltételek között az egyébként gyengébb üzemek is közelebb kerülnek az adott technológiai színvonal mellett potenciálisan elérhető kibocsátáshoz. Kevésbé kedvező időjárás esetén viszont megnövekszik az üzemek technikai hatékonysága közötti különbség, és ennek köszönhetően az átlagos TFP érték az előző évi értékhez képest nagyobb eltérést is mutathat. Az időjárási kockázat mellett az üzemek rendelkezésére álló inputok és outputok ára és mennyisége is befolyásolja a TFP alakulását. 2009-ben az előző évekhez képest magasabb inputárak és az alacsonyabb hozamok hatására csökkent a TFP értéke.

A kedvezőtlen időjárási hatásokat a TFP számítása során háromtagú mozgóátlagolással simítottam ki. Mozgóátlagolás után a vizsgált időszakban a TFP és összetevőinek általános tendenciája ugyan az maradt, csak az évenkénti zavaró hatások kerültek kiszűrésre az idősorból. A vizsgált időszakban a magyarországi szántóföldi növénytermelés teljes tényezős termelékenységének éves növekedési ütemét mutatja a 3. ábra méretkategóriákra és a teljes szántóföldi növénytermelésre összesen.

A folyamatosan szántóföldi növénytermelési tevékenységet végző üzemek teljes tényezős termelékenysége 1,78\%-kal javult a vizsgált időszakban. Ezt a növekedést az élvonalbeli gazdaságok 1,69\%-os teljesítményjavulása, valamint a követő gazdaságok 0,08\%-os technikai hatékonyságjavulása okozta. A technikai hatékonyság változását kismértékű méretcsökkenés (-0,07\%) és a termelési tényezők 0,16\%-kal hatékonyabb felhasználása okozta.

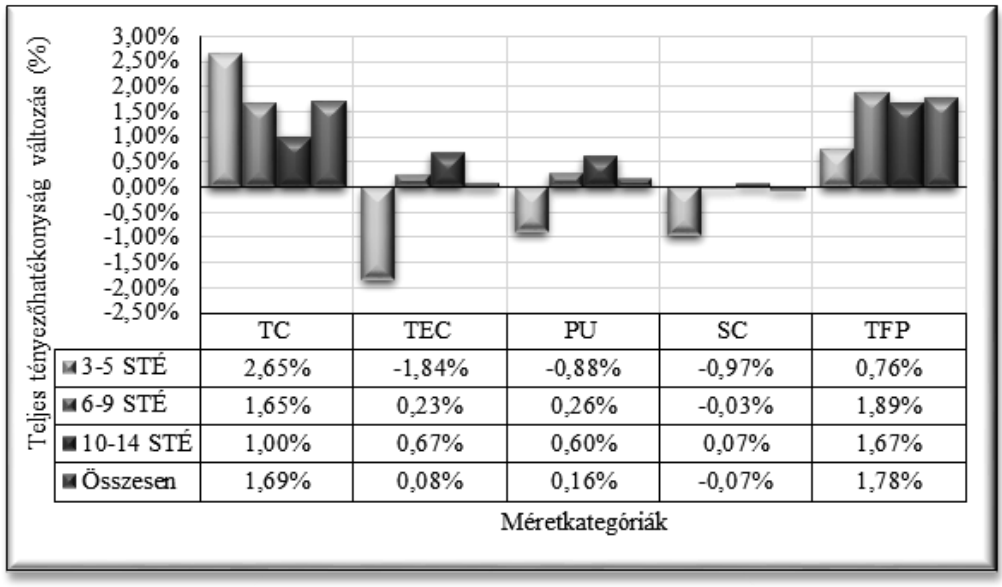

3. ábra: A szántóföldi növénytermelés teljes tényezős termelékenységének és összetevőinek éves növekedési üteme Magyarországon 2004-2015 között (\%)

Forrás: AKI adatok alapján saját számitás, DEAP 
Az egyes méretkategóriák tekintetében a 3-5 STÉ-vel rendelkező üzemek TFPje növekedett a legkisebb mértékben. Ugyanakkor ennél a méretkategóriánál volt a legmagasabb a termelés hatékonyságának javulása (2,65\%). Ezt a hatékonyságjavulást a követő gazdaságok nem tudták produkálni. Az új technológiákra való lassabb áttérés 1,84\%-kal csökkentette a teljes tényezős termelékenységet. Ezt a csökkenést szinte azonos súllyal okozta a termelés méretének csökkenése és a tiszta technikai hatékonyság mutatójának csökkenése.

A 6-9 STÉ-vel rendelkező üzemek termelékenysége (1,89\%) javult a legnagyobb mértékben a vizsgált méretkategóriák közül. Ezt a növekedést 1,65\%-ban az élvonalbeli üzemek teljesítményének javulása, valamint 0,23\%-ban a követő üzemek technológiai hatékonyságának javulása okozta. A 6-9 STÉ-vel rendelkező üzemek méretgazdaságossága a másik két méretkategóriához viszonyítva szinte alig változott, míg a termelési tényezők optimálisabb felhasználásából és a menedzsment felkészültségéből adódó hatékonyság javulás $0,26 \%$ volt.

A 10-14 STÉ-vel rendelkező üzemek teljes tényezős termelékenysége 1,67\%-kal növekedett. Az ebbe a méretkategóriába tartozó élvonalbeli üzemek hatékonysága javult a legkisebb mértékben (1,00\%), viszont az új technológiákra való áttérésből adódó technikai hatékonyságváltozás ennél a méretkategóriánál volt a legmagasabb $(0,67 \%)$. Ez a hatékonyságjavulás 0,07\%-ban a mérethatékonyság növekedésének és 0,60\%-ban a tiszta technikai hatékonyságváltozás növekedésének volt köszönhető. A menedzsment felkészültségéből adódó hatékonyságváltozás ennél a méretkategóriánál volt a legmagasabb.

\begin{tabular}{|l|l|l|l|l|l|l|l|}
\hline Felhasználás módja & $\mathbf{2 0 1 3}$ & $\mathbf{2 0 1 4}$ & $\mathbf{2 0 1 5}$ & $\mathbf{2 0 1 6}$ & $\mathbf{2 0 1 7}$ & Átlag & $\begin{array}{l}\text { Átlagos éves } \\
\text { növekedési } \\
\text { ütem }\end{array}$ \\
\hline Ipari feldolgozás & 15,13 & 13,78 & 14,88 & 17,10 & 16,94 & 15,22 & 2,87 \\
\hline $\begin{array}{l}\text { - Ebből belföldi } \\
\text { élelmezés }\end{array}$ & 9,67 & 8,02 & 7,84 & 7,48 & 7,21 & 8,25 & $-7,07$ \\
\hline - Ebből nem élelmezésre & 5,46 & 5,76 & 7,05 & 9,62 & 9,73 & 6,97 & 15,54 \\
\hline Takarmányfelhasználás & 18,78 & 16,31 & 15,57 & 14,71 & 13,78 & 16,35 & $-7,44$ \\
\hline Kivitel & 26,50 & 22,37 & 27,07 & 21,40 & 27,95 & 24,33 & 1,34 \\
\hline
\end{tabular}

1. táblázat: A gabonafélék főbb felhasználási módjának alakulása Magyarországon (\%) Forrás: KSH, 2019

A Malmquist index segítségével számszerüsített 1,78\%-os érték aggregáltan tartalmazza az AKI adatbázisában szereplő folyamatosan szántóföldi növénytermelési tevékenységet végző üzemek termelékenységének növekedését 2004 és 2015 közötti időszakra. Számos tényező hozzájárult a szántóföldi növénytermelés 
termelékenységének növekedéséhez, mint például a termelési szerkezet változása, a megtermelt termények felhasználási módjának változása, valamint az egyéb gazdasági folyamatok alakulása.

A Magyarországon megtermelt gabonafélék felhasználásának változását mutatja az 1. táblázat. Az egyes években a Magyarországon rendelkezésre álló gabonamennyiségből átlagosan 15\% élelmiszer és ipari célú felhasználásra, 16\% takarmányozásra és 24\% export célokra került felhasználásra, a maradék pedig készletre került. Az állatállomány csökkenésével az 1990-es évek óta a gabonafélék takarmányozási célú felhasználása csökkent, valamint az élelmiszer célú felhasználás is csökkenő tendenciát mutat. Növekedés csak az ipari célú felhasználásban és az export mennyiségében következett be, tehát a termelékenység növekedése alapvetően ennek a két tényezőnek volt köszönhető.

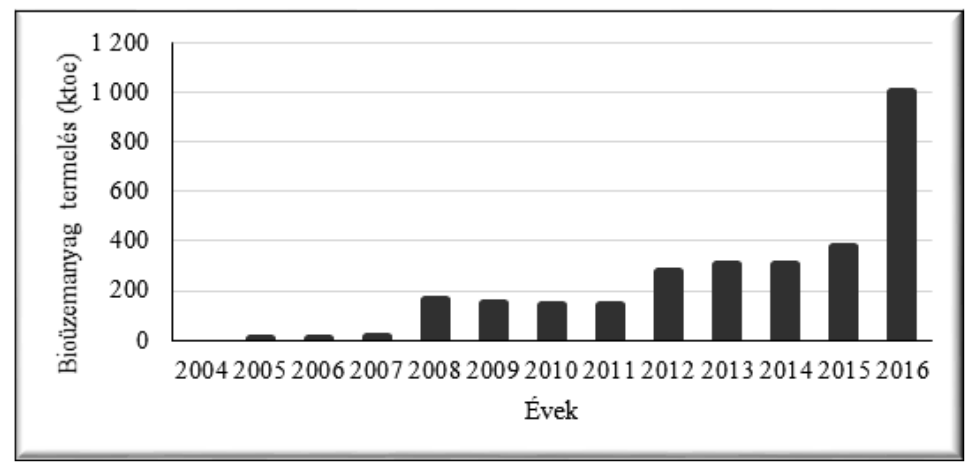

\section{4. ábra: A bioüzemanyag termelés alakulása Magyarországon} Forrás: EUROSTAT, 2016

Az ipari felhasználás növekedésének nagyobb hatása volt a termelékenység növekedésére, mint az export növekedésének. Magyarországon a gabonafélék ipari célú felhasználásán belül a hagyományos bioüzemanyagok gyártása 2005-től új iparágként jelentkezett. A hazai termelés 2008 és 2016 között hatszorosára növekedett (4. ábra). Jelenleg a Magyarországon megtermelt gabonamennyiség körülbelül 1012\%-a kerül energetikai célokra felhasználásra, mely mennyiség szintén hozzájárul a szántóföldi növénytermelés termelékenységének növekedéséhez. Az exportált gabona egy része valószínủleg szintén bioüzemanyag előállításra kerül felhasználásra, de erre vonatkozóan nem állnak rendelkezésre adatok. 


\section{Következtetések, javaslatok}

Magyarországon a folyamatosan szántóföldi növénytermeléssel foglalkozó üzemek termelékenysége kismértékű javulást mutat a vizsgált időszakban. A közepes méretű szántóföldi növénytermelő üzemek termelékenysége alakult a legkedvezőbben, míg a kisméretű élvonalbeli üzemek termelési szintje került közelebb az adott technológia által maximálisan elérhető termelési lehetőségek határához. A nagyméretű üzemek viszont sokkal jobban ki tudták használni a rendelkezésükre álló termelési tényezőket. A menedzsment felkészültsége, képzettsége magasabb volt, szemben a kisméretű üzemekkel, melyek jelentősen lemaradtak a technológia fejlesztésében.

Magyarországon az állatállomány csökkenésével a gabonafélék takarmányozási célú felhasználása csökkent, valamint az élelmiszer célú felhasználás is csökkenő tendenciát mutat. Növekedés csak az ipari célú felhasználásban és az export mennyiségében következett be, tehát a termelékenység növekedése alapvetően ennek a két tényezőnek volt köszönhető. A szántóföldi növénytermelés termelékenységének növekedésére az ipari felhasználásnak volt nagyobb a hatása. Az ipari célú felhasználás a bioüzemanyag termelés mellett egyéb ipari tevékenységeket is tartalmaz. Mivel a bioüzemanyag termelés mennyisége Magyarországon jelentősen megugrott 2008 után, ezért arra lehet következtetni, hogy a termelékenység növekedéséhez jelentősen hozzájárult a bioüzemanyagok előállítása. Az exportált gabona egy része valószínűleg szintén bioüzemanyag előállításra került felhasználásra.

Magyarországon a szántóföldi növénytermelés termelékenységének növekedését a technikai hatékonyság növelésével lehetne tovább javítani. Ehhez egyrészt a mérethatékonyságon, vagyis a termelési tényezők hatékonyabb felhasználásán kellene javítani, másrészt a menedzsment felkészültségét kellene növelni. Az új technológiák alkalmazásához nem elegendő a hagyományok alapján történő gazdálkodás, hanem megfelelő szakértelem is kell hozzá, amit továbbképzéssel, a menedzseri képességek javításával érhetnek el a gazdák. A technikai hatékonyság növelése föleg a kisméretü gazdaságok számára lenne a legfontosabb, mert az ebbe a méretkategóriába tartozó üzemek technikai hatékonysága a vizsgált időszakban csökkent. 


\section{Hivatkozott források}

[1.] Baranyi A., Csernák J., Pataki L., Széles Zs. (2012): A magyar mezőgazdasági vállalkozások vagyoni, pénzügyi helyzetének elemzése, összehasonlítva az erdőgazdálkodást folytató vállalkozások teljesítményével Közgazdász Fórum / Forum on Economics and Business 15 (105) pp. 53-80. (2012)

[2.] Baráth L., Hockmann, H., Keszthelyi Sz., Szabó G. (2009): A teljes tényezős termelékenység változásának forrásai a magyar mezőgazdaságban (20012006), Statisztikai Szemle, 87. (5.), p. 471-492

[3.] Coelli, T. J., Rao, D. S. P., O’Conell, C. J., BATTESE, G. E. (2005): An Introduction to Efficiency and Productivity Analysis, Springer, Second Edition, 349 p.

[4.] Eurostat (2016): Supply, transformation and consumption of renewable energies - annual data (nrg_107a), Online: http://ec.europa.eu/eurostat/ data/database, Keresőprogram: Google, Kulcsszavak: eurostat, Letöltés: 2016.06.14

[5.] Färe, R., Grosskopf, S. (1998): The Professional Tool for Efficiency and Productivity Measurement, Reference Guide to OnFront, Economic Measurement and Quality Corporation, $52 \mathrm{p}$.

[6.] Farkasné F. M., Szűcs I., Varga T. (2008): A relatív hatékonyság mérésének módszere és gyakorlati alkalmazások: Hatékonysági összetevők vizsgálata Malmquist-index alkalmazásával a fontosabb mezőgazdasági ágazatokban, In: SZÜCS I., FARKASNÉ F. M. (2008): Hatékonyság a mezögazdaságban (Elmélet és gyakorlat), Budapest: Agroinform Kiadó, 357 p.

[7.] Farkasné F. M., Szűcs I., Varga T. (2009): Malmquist-index alkalmazása a komplex tényező hatékonyság mérésére, Miskolci Egyetem, Gazdaságtudományi Kar, VII. Nemzetközi Konferencia, p. 102-109.

[8.] KSH (2019): A fontosabb gabonafélék termesztése és felhasználása (2013), Online: http://www.ksh.hu/docs/hun/xstadat/xstadat_eves/i_omn002a. html, Keresőprogram: Google, Kulcsszavak: ksh, gabonafélék termesztése és felhasználása, Letöltés: 2019.02.02

[9.] Somai M. (2004): A magyar mezőgazdaság átalakulása I., Biológiai alapok, struktúraváltás, termelői jövedelmek, Magyar Tudományos Akadémia, Világgazdasági Kutatóintézet, Mühelytanulmányok, 64., 22 p. 


\section{Szerző:}

\section{Lászlók Anett}

Szent István Egyetem

Gazdálkodás és Szervezéstudományok Doktori Iskola

Doktorjelölt

laszlok.anett@gmail.com 